\title{
Unpasteurized milk from the bulk tank used for calf-feeding might increase incidence of BLV in dairy farms
}

\author{
Natalia G Porta*, Juan P Jaworski, Rozana Galarza, Geronimo Gutierrez, Romina P Politzki, Irene Álvarez, \\ Luis Calvinhos, Karina G Trono
}

From 17th International Conference on Human Retroviruses: HTLV and Related Viruses

Trois llets, Martinique. 18-21 June 2015

We think that the ingestion of milk with provirus or free virus particles could be important for BLV vertical transmission in calves. In order to explore this idea we conducted an epidemiological study in an experimental milking facility $(8,0 \mathrm{Kg} / \mathrm{animal} /$ year $)$. The herd was composed by 332 dairy cattle and their calves were fed using non-pasteurized milk from the bulk tank located at the milking parlor. Blood and milk samples were obtained from 49 randomly selected animals. In addition, we collected 10 milk samples from the bulk tank along a onemonth period. We tested all samples for the presence and quantity of BLV DNA and BLV-specific antibodies (Abs). We observed an individual serological prevalence of $94 \%$ and $96 \%$ considering the whole dairy herd $(n=332)$ and the subgroup of animals $(n=49)$, respectively. From the latest group we detected the presence of BLV DNA in $60 \%$ and $30 \%$ of blood and milk samples, respectively. In addition we detected BLV Abs in $90 \%$ of individual milk samples. Then, we assayed milk samples from the bulk tank $(\mathrm{n}=10)$ detecting BLV Abs in all cases and the presence of BLV DNA in 8 out of 10 opportunities. Finally, we observed a weak positive correlation between the levels of cell associated viral load (CAVL) in blood and BLV Abs in serum and milk. The overall prevalence described here is in agreement with the one described for other farms with a similar level of production. Furthermore, we found that there were a higher proportion of milk samples carrying BLV DNA in the bulk tank compared to individual milk samples. Feeding calves using unpasteurized milk from this source could increase the risk of transmission by at least

Instituto de Virología, C.I.C.V. y A., Instituto Nacional de Tecnología AgropecuariaEEA Rafaela, Buenos Aires, Argentina one of the following ways: (i) increasing the frequency of provirus intake by the calf and (ii) disrupting the natural balance between provirus and Abs that the calf receives directly from his mother.

Published: 28 August 2015

doi:10.1186/1742-4690-12-S1-P38

Cite this article as: Porta et al:: Unpasteurized milk from the bulk tank used for calf-feeding might increase incidence of BLV in dairy farms. Retrovirology 2015 12(Suppl 1):P38.
Submit your next manuscript to BioMed Central and take full advantage of:

- Convenient online submission

- Thorough peer review

- No space constraints or color figure charges

- Immediate publication on acceptance

- Inclusion in PubMed, CAS, Scopus and Google Scholar

- Research which is freely available for redistribution
() Biomed Central 